\title{
Report fuels criticism of UK research council
}

Natasha McDowell, London

For years, critics of Britain's Medical Research Council (MRC) have quietly grumbled that the prestigious funding agency doesn't plan its priorities carefully enough, or communicate properly with the community of researchers that it supports. Now the detractors are claiming vindication after a scathing report from a parliamentary committee endorsed their views.

The report, released on 25 March, says that the MRC has grown distant from many medical researchers. The committee accuses the council of "inconsistent and inadequate communication", and of allocating too much money to big projects, such as the UK Biobank genetic database, leaving itself unable to fund as many individual grants as it had led researchers to expect (see Nature $418,714 ; 2002)$. "The recent success rate for the MRC's grant applications has fallen to levels that are unacceptable," the report says, adding that researchers' anger at this is "entirely justified".

George Radda, a biochemist and chief executive of the MRC, says that many of the charges levelled by the House of Commons' Science and Technology Select Committee result from "misunderstandings" about what the agency is doing.

But several medical researchers contacted by Nature say that the charges are broadly justified. "In my view - and that of most of my colleagues - the criticisms are just about on the mark," says David Colquhoun, a pharmacologist at University College London.

"A lot of what is in the report is valid and fair, and the MRC needs to take note," says David Price, a physiologist at the University of Edinburgh and one of the scientists who testified before the committee.

"The MRC has a good track record, but in the past few years it has gone to pieces," says Ian Gibson (Labour, Norwich North), the committee's chairman. The harsh language in the report reflects the views of organizations and senior scientists who testified before the committee, he says. He adds that, in his view, the MRC is run by a small, London-based group that is not fully representative of medical researchers around the country.

Radda defends the decision to back the UK Biobank, to which the MRC has pledged $\mathfrak{E 2}$ million (US\$32 million) over seven years. "We have a responsibility to set up national facilities that support science in the longer term," he says. But he says that the MRC should have done more to inform scientists of its financial situation. "We now have a very detailed statement on our website about funding between 2003 and 2006," he adds.

And William Stewart, a microbiologist and former chief scientific adviser to the
British government, says that Gibson's committee has in the past been overly critical and might have been more constructive in this case. "They should be fighting for more money for science," he comments, "but there's no mention here of the MRC's need for more funds."

The government is due to respond to the report within two months, and its officials had no comment last week on what it will do about the barrage of criticism levelled at the council. But Peter Cotgreave, director of the pressure group Save British Science, thinks the findings will encourage more energetic communication from the MRC and discourage further commitments to large projects. "If they commit money long-term next time, having had these problems pointed out, they will be asking for trouble, and may not get funded," he suggests. "The other research councils will argue that they should get more money because they know how to spend it."



George Radda, head of the MRC, defends the allocation of money for longer-term research.

\section{Biosphere owner sues sponsor}

\section{Virginia Gewin, Portland}

The owner of Biosphere 2 - an experiment to build a carefully controlled ecosystem in a massive Arizona greenhouse - is suing Columbia University in New York over its plan to withdraw support from the facility.

Decision Investments Corporation, a company controlled by the Texan billionaire Ed Bass, who built Biosphere 2, filed a lawsuit against the university in Arizona's superior court on 21 March. Two months ago, the company was notified that Columbia wanted to get out of its ten-year, \$20-million contract to manage the facility until 2010, by June (see Nature 421, 466; 2003).

The conflict arises as Biosphere 2 takes steps towards attaining the scientific credibility it has sought since its construction 15 years ago. Earlier this year, for example, chemists there demonstrated that elevated atmospheric carbon dioxide levels could offset negative air-quality effects associated with planned forests (T. N. Rosenstiel et al. Nature 421, 256-259; 2003).

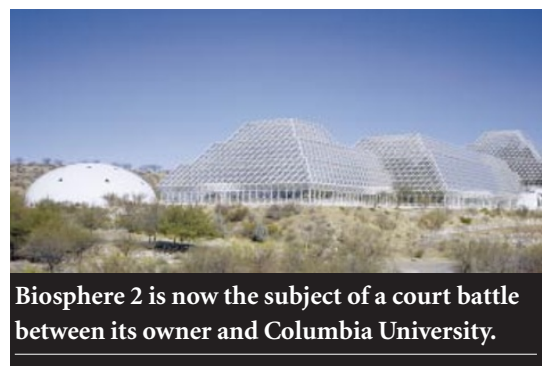

The lawsuit alleges that Columbia is in breach of contract by abandoning plans for new education programmes, an extra lab and the recruitment of half-a-dozen senior researchers at Biosphere 2. "For years, Columbia has affirmed that the education and science tracks were proceeding with much success, and then, out of the blue, they want to cease funding the project they designated as their 'western campus' three years ago," says Martin Bowen, vicepresident of Decision Investments. A spokeswoman for Columbia declined to comment on the lawsuit.

A statement by Decision Investments ascribed Columbia's move to a recent change of leadership - economist Jeffrey Sachs took over last April as director of Columbia University's Earth Institute. But Sachs says the institute will maintain its commitment to ecological research, and that any speculation to the contrary is "totally unfounded and completely misinformed".

Biosphere 2 managers say they plan to keep operating the facility and to find alternative sources for its annual operating costs of about $\$ 1.5$ million. They say that European researchers, including groups from Jena, Germany, and Edinburgh and remain committed to the experiment.

Joe Berry, a Biosphere 2 ecologist based at the Stanford University branch of the Carnegie Institution of Washington, says he thinks that the facility could one day sustain itself through grants if a critical mass of good-quality scientific output is reached. 